\title{
Cyclin D3 in the mouse uterus is associated with the decidualization process during early pregnancy
}

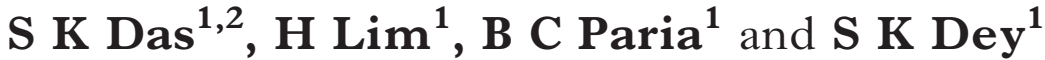

\author{
${ }^{1}$ Department of Molecular and Integrative Physiology, Ralph L Smith Research Center, University of \\ Kansas Medical Center, Kansas City, Kansas 66160-7338, USA \\ ${ }^{2}$ Department of Obstetrics and Gynecology, Ralph L Smith Research Center, University of Kansas \\ Medical Center, Kansas City, Kansas 66160-7338, USA \\ (Requests for offprints should be addressed to S K Das, Departments of Molecular and Integrative \\ Physiology and Obstetrics and Gynecology, University of Kansas Medical Center, MRRC 37/3007, \\ 39th and Rainbow Boulevard, Kansas City, Kansas 66160-7338, USA)
}

\begin{abstract}
In the mouse, the attachment reaction between the blastocyst trophectoderm and the receptive uterine luminal epithelium occurs at 2200-2300 h on day 4 of pregnancy and is rapidly followed by transformation of stromal cells into decidual cells (decidual cell reaction). This process can also be induced experimentally (deciduoma) by intraluminal oil infusion in the uterus on day 4 of pseudopregnancy. The decidual cell reaction is associated with up- and down-regulation of many genes in a cell-specific manner. Using mRNA differential display, we identified cyclin D3 as one of the genes that is upregulated in the uterus at the sites of blastocyst apposition during the attachment reaction. The levels of expression were low in the morning of days 1-4 as determined by Northern hybridization. In situ hybridization analysis showed that on days 1 and 2 , signals were primarily localized in uterine epithelial cells, while signals were detected in both the stromal and epithelial cells on days 3 and 4 . In contrast, with the initiation and progression of decidualization on days 5, 6 and 7, the levels of cyclin D3 mRNA were remarkably upregulated in stromal cells both at the mesometrial and the
\end{abstract}

antimesometrial poles. However, on day 8 , signals were primarily localized in stromal cells at the mesometrial decidual bed. Implanting blastocysts on these days also expressed cyclin D3 mRNA. In the progesterone-treated delayed implanting mice, the uterine levels of cyclin D3 mRNA were modest at the sites of blastocyst apposition, but were upregulated with the onset of implantation by estradiol-17 $\beta$. However, the decidual expression of cyclin D3 mRNA was not dependent on the presence of blastocysts, since increased expression also occurred in experimentally induced deciduoma in the absence of blastocysts. The importance of cyclin D3 in decidualization was further examined in Hoxa-10-deficient mice which show defective decidualization. The expression of cyclin D3 mRNA in Hoxa-10 $(-/-)$ uteri on day 5 was severely compromised after application of a deciduogenic stimulus on day 4 of pseudopregnancy. Collectively, the results suggest that cyclin D3 could be important for the process of decidualization.

Fournal of Molecular Endocrinology (1999) 22, 91-101

\section{INTRODUCTION}

The differentiation of the uterus to support embryo development and implantation is primarily coordinated by progesterone $\left(\mathrm{P}_{4}\right)$ and estrogen (Psychoyos 1973, Paria et al. 1993a). In the rodent, the first conspicuous sign of implantation is an increased endometrial vascular permeability at the sites of blastocyst apposition (Psychoyos 1973, Paria et al. 1993a). This increased vascular permeability coincides with the initial attachment reaction between the blastocyst trophectoderm and uterine luminal epithelium (Enders \& Schlafke 1967). In the mouse, this reaction occurs in the evening $(2200-2300 \mathrm{~h})$ of day 4 of pregnancy and is preceded by uterine luminal closure, which in turn results in an intimate apposition of the trophectoderm with the luminal epithelium (Psychoyos 1973, Enders 1976, Enders \& Schlafke 1967, Das et al. 1994). Ovariectomy in the morning of day 4 of pregnancy, 
prior to preimplantation ovarian estrogen secretion, results in blastocyst dormancy and failure of implantation, a condition known as delayed implantation. Delayed implantation can be maintained by continued $\mathrm{P}_{4}$ treatment, but is terminated by an injection of estrogen which induces blastocyst activation and initiation of the attachment reaction (Yoshinaga \& Adams 1966, Paria et al. 1993a,b). The luminal closure and apposition occur during the $\mathrm{P}_{4}$-treated delayed implantation, but the attachment reaction (uterine blue reaction) and the subsequent events do not occur unless estrogen is provided (Psychoyos 1973, Nilsson 1974, Enders 1976).

The uterus is composed of heterogeneous cell types which respond uniquely to estrogen and $\mathrm{P}_{4}$. In the adult ovariectomized mouse uterus, estrogen stimulates proliferation of epithelial cells, while this process in the stroma requires both $\mathrm{P}_{4}$ and estrogen (Huet-Hudson et al. 1989). A similar steroid hormonal regulation occurs during the periimplantation period. On days 1 and 2, preovulatory ovarian estrogen directs epithelial cell proliferation. On day $3, \mathrm{P}_{4}$ from newly formed corpora lutea initiates stromal cell proliferation, which is further potentiated by preimplantation ovarian estrogen secretion on day 4 . In contrast, epithelial cells cease to proliferate and become differentiated on this day. With the initiation of blastocyst attachment reaction, stromal cells at sites of blastocyst apposition undergo proliferation and differentiation into decidual cells (Huet-Hudson et al. 1989). In pregnant mice, the stimulus for decidualization is the implanting blastocyst. On day 5 at the beginning of decidual cell reaction, only stromal cells surrounding the implanting blastocyst proliferate. On day 6, the stromal cells in immediate proximity to blastocyst apposition cease to proliferate and form the primary decidual zone (PDZ). However, the cells outside the PDZ continue to proliferate and form the secondary decidual zone (SDZ) (Dey 1996). This process can also be induced artificially in the pseudopregnant or steroid hormonally prepared uterus by intraluminal infusion of oil ( Lim et al. 1997).

The best known regulators of mammalian cell proliferation are the three D-type cyclins (D1, D2 and D3), commonly referred as G1 cyclins, which are considered to be the key regulators of cell proliferation and transition of G1/S phase in the cell cycle (Hunter \& Pines 1994, Sherr 1994, Grana \& Reddy 1995, Herzinger \& Reed 1998). These proteins mediate their action after binding to catalytic subunits of specific cyclin-dependent kinases (cdk-2, -4, -5 and -6) (Sherr 1994, Grana $\&$ Reddy 1995). The association of D-type cyclins to the holoenzymes of $\mathrm{p} 34^{\mathrm{cdk}-4}$ and $\mathrm{p} 38^{\mathrm{cdk}-6}$ is particularly important for these cyclin proteins to function as positive regulators of G1 progression, whereas the cyclin D-p32 $2^{\text {cdk-2 }}$ holoenzyme complex is inactive during the G1 phase (Pines 1995). However, the latter is required later during the $\mathrm{S}$-phase progression and S/G2 transition. The actions of D-type cyclins are negatively controlled by the retinoblastoma proteins (pRB) and the progression through $\mathrm{G} 1$ phase requires inactivation of the pRB protein by phosphorylation (Weinberg 1995).

During embryo implantation, the proliferation and differentiation events in the endometrial compartment are associated with up- or downregulation of several genes in the uterus at the sites of blastocyst attachment. Using the technique of differential display of mRNAs, we sought to identify the genes which are primarily regulated at the time of implantation in the uterus. In the present investigation, we provide evidence that the expression of cyclin D3 mRNA is distinctly upregulated in the mouse uterus at the sites of implantation and the expression is correlated with the process of decidualization.

\section{MATERIALS AND METHODS}

\section{Animals and tissue preparation}

CD-1 (Charles River Laboratories, Raleigh, NC, USA) and Hoxa-10(-/-) were housed in the animal care facility at the University of Kansas Medical Center in accordance with NIH standards for the care and use of experimental animals. Adult females were mated with fertile or vasectomized males of the same strain to induce pregnancy or pseudopregnancy respectively (day $1=$ day of vaginal plug). For differential display studies, mice were killed on day 4 of pregnancy or pseudopregnancy at $1800 \mathrm{~h}$ and on day 4 of pregnancy at $2300 \mathrm{~h}$ (the time of the attachment reaction). Pregnant uteri were gently flushed with saline to recover blastocysts. Whole uteri at $1800 \mathrm{~h}$ or the implantation sites at $2300 \mathrm{~h}$ were collected and processed for RNA.

Pregnancy on days 1-4 was confirmed by recovering embryos from the reproductive tracts. On the evening of day $4(2300 \mathrm{~h})$ at the time of attachment reaction or on days 5-6, implantation sites were identified by monitoring the localized uterine vascular permeability at the sites of blastocysts after intravenous injection of Chicago Blue B solution in saline. Implantation sites were demarcated by discrete blue bands along the uterus (Paria et al. 1993a). On days 7 and 8, implantation sites are distinct and their identification does not 
require any special manipulation. Mice on days 1-8 were killed at $0830-0900 \mathrm{~h}$ and their uteri were collected for RNA extraction and in situ hybridization. To induce and maintain delayed implantation, mice were ovariectomized in the morning $(0800-0900 \mathrm{~h})$ of day 4 of pregnancy and received daily injections of $\mathrm{P}_{4}(2 \mathrm{mg} / \mathrm{mouse})$ from days 5-7 (Yoshinaga \& Adams 1966, Paria et al. 1993b). To terminate delayed implantation and to induce blastocyst activation, the $\mathrm{P}_{4}$-primed delayed implanting mice were given an injection of estradiol$17 \beta\left(\mathrm{E}_{2}, 25 \mathrm{ng} /\right.$ mouse $)$ on the third day of the delay (day 7). Mice were killed $24 \mathrm{~h}$ after treatment with the respective steroid hormones and their uteri were collected for in situ hybridization. The first visually detectable implantation sites after blue dye injection normally become evident $18-24 \mathrm{~h}$ after an $\mathrm{E}_{2}$ injection.

To induce artificial decidualization, sesame oil $(25 \mu \mathrm{l})$ was infused intraluminally in one uterine horn on day 4 of pseudopregnancy; the contralateral horn served as a control. Decidual cell reaction was confirmed by recording uterine weight and histological examination of uterine sections on days 7 and 8 of pseudopregnancy (Lim et al. 1997).

\section{Differential display of mRNA}

Differential display was performed as described previously with some modifications (Liang et al. 1993). Total RNA was extracted from tissues by a modified guanidine thiocyanate procedure (Han et al. 1987, Das et al. 1994). DNA-free RNA was obtained by treatment of total cellular RNA $(50 \mu \mathrm{g})$ with RNase-free DNase I (Sigma Chemical Co., St Louis, MO, USA) in the presence of placental RNase inhibitor (BRL, Gaithersburg, MD, USA) for $30 \mathrm{~min}$ at $37^{\circ} \mathrm{C}$. After phenol:chloroform $(3: 1)$ extraction, RNA was precipitated with $0.3 \mathrm{M}$ sodium acetate and ethanol. The RNA pellet was dissolved in diethyl pyrocarbonate-treated water, and $1.0 \mu \mathrm{g}$ total RNA was used for reverse transcription (RT) reactions using three different one-base anchored primers as described by Liang et al. (1994), with a modification as follows: LHT $_{11}$ C (5'-TGCCGAAGCTTTTTTTTTTTC-3'), LHT $_{11}$ G (5'-TGCCGAAGCTTTTTTTTTTTG-3') and LHT $_{11} \mathrm{~A}$ (5'-TGCCGAAGCTTTTTTTT'T TTA-3'). The protocol for the RT reaction was the same as previously described (Paria et al. 1993b). The polymerase chain reaction (PCR) was performed in a reaction mixture containing $0 \cdot 1$ volume of the RT product, $1 \times$ PCR buffer $(10 \mathrm{mM}$ Tris- $\mathrm{HCl}$, pH $8 \cdot 3 ; 2.5 \mathrm{mM} \mathrm{MgCl}_{2}$ and $50 \mathrm{mM}$ $\mathrm{KCl}), 600 \mu \mathrm{M}$ each of dATP, dTTP, dGTP and dCTP, $500 \mu \mathrm{Ci} / \mathrm{ml}^{35} \mathrm{~S}$-dATP $(1200 \mathrm{Ci} / \mathrm{mmol}$, New
England Nuclear, Boston, MA, USA), $0 \cdot 5 \mu \mathrm{M}$ of the respective primer: $\mathrm{LHT}_{11} \mathrm{C}, \mathrm{LHT}_{11} \mathrm{G}$ or $\mathrm{LHT}_{11} \mathrm{~A}, 0.5 \mu \mathrm{M}$ of the arbitrary primer and 20 units/ml Ampli Taq DNA polymerase (Perkin-Elmer Cetus, Norwalk, CT, USA). The arbitrary primers were designed as described by Liang et al. (1994), with some modifications as follows: LHAP1, 5'-TGCCGAAGCTTGATT GCC-3', LHAP2, 5'-TGCCGAAGCTTCGAC TGT-3' or LHAP3, 5'-TGCCGAAGCTTTGGT CAG-3'. PCR reaction was performed in a Perkin-Elmer 480 thermocycler, using cycling parameters as follows: first cycle at $94{ }^{\circ} \mathrm{C}$ for $1 \mathrm{~min}$, $40{ }^{\circ} \mathrm{C}$ for $4 \mathrm{~min}$ and $72{ }^{\circ} \mathrm{C}$ for $1 \mathrm{~min}$ followed by 35 cycles at $94{ }^{\circ} \mathrm{C}$ for $45 \mathrm{~s}, 60{ }^{\circ} \mathrm{C}$ for 2 min and $72{ }^{\circ} \mathrm{C}$ for $1 \mathrm{~min}$. The amplified cDNAs were separated on a 6\% DNA sequencing gel. After electrophoresis, gels were transferred to $3 \mathrm{MM}$ paper (Whatman, Maidstone, Kent, UK), dried and exposed to Kodak XAR-5 film for 36-72 h. Differentially displayed bands of interest were identified, cut out from the gel, and DNA was eluted as described (Liang et al. 1993). The individual eluted bands were reamplified by PCR using the appropriate primers and the reaction conditions as described above. Aliquots $(5 \mu \mathrm{l})$ of the reamplified bands were examined on $1 \%$ agarose gels stained with ethidium bromide to ensure that correct sizes of fragments were generated during the second round of amplification. The remaining amplified products were then used to clone into the pCR-Script SK(+) vector (Stratagene cloning systems, Stratagene, La Jolla, CA, USA) according to the manufacturer's instructions.

\section{Sequencing of cDNA subclones of PCR fragments, Northern and Southern blot analysis}

Double-stranded DNA sequencing was carried out with either T7 or T3 primers using the SequiTherm long-read cycle sequencing kit LC (Epicenter Technologies, Madison, WI, USA) according to the manufacturer's specification. The nucleotide sequences were analyzed by the BLAST Sequence Similarity Searching Program (blastn) using the GenBank sequence databases available at the National Center for Biotechnology Information, National Institute of Health, USA.

Radiolabeled $\left[{ }^{32} \mathrm{P}\right] \mathrm{cRNA}$ antisense probes were generated from cDNA clones by $\mathrm{T} 7$ or T3 RNA polymerases and analyzed by Northern and Southern blot hybridization. Total RNA $(6 \cdot 0 \mu \mathrm{g})$ was used for Northern blotting, and mouse tail DNA $(5 \cdot 0 \mu \mathrm{g})$ digested with different restriction enzymes (BamHI, EcoRI, BamHI+EcoRI, HindIII, SmaI, 
HindIII+SmaI) was subjected to Southern blotting. In general, both Northern and Southern blots were prehybridized and hybridized at high stringency using the same protocol as previously described (Das et al. 1994, 1995). Briefly, hybridization was carried out for $20 \mathrm{~h}$ at $68^{\circ} \mathrm{C}$ in $3 \times \mathrm{SET}(1 \times \mathrm{SET}=150 \mathrm{mM}$ $\mathrm{NaCl}, 5 \mathrm{mM}$ EDTA and $10 \mathrm{mM}$ Tris-HCl, pH 8.0), $20 \mathrm{mM}$ phosphate buffer $(\mathrm{pH} 7 \cdot 2), 250 \mu \mathrm{g} / \mathrm{ml}$ tRNA, $10 \%$ dextran sulfate and $\approx 2 \times 10^{6}$ counts/ min ${ }^{32} \mathrm{P}$-labeled antisense RNA probe/ml of the hybridization buffer. After hybridization, the blots were washed once in $1 \times \mathrm{SSC}, 0 \cdot 1 \% \mathrm{SDS}$ for $1 \mathrm{~h}$ at $68{ }^{\circ} \mathrm{C}$, followed by a second wash in $0 \cdot 3 \times \mathrm{SSC}, 0 \cdot 1 \%$ SDS for $1 \mathrm{~h}$ at $68^{\circ} \mathrm{C}$; the hybrids were detected by autoradiography. Stripping of the hybridized probe before subsequent rehybridization for the Northern blots was achieved as previously described (Das et al. 1995). Each blot was first hybridized to a clonespecific probe and then to the ribosomal protein L-7 (rpL7) probe to confirm integrity, equal loading and blotting of RNA samples.

\section{Hybridization probes}

By differential display cDNA cloning, we obtained a clone $(3 \mathrm{CBo})$ of approximately $450 \mathrm{bp}$, exactly identical to the sequences of the $3^{\prime}$-end of the mouse cyclin D3 cDNA. In addition, by RT-PCR amplification, we obtained an additional cDNA fragment containing the sequences, 1682-1980 nts (GenBank accession \# U43844) for mouse cyclin D3 using total RNA on day 5 of pregnancy and subcloned this fragment into the pCR-Script SK $(+)$ vector. The authenticity of this clone was determined by sequence analysis. This clone $(\mathrm{Cd} 3)$ was used to compare our results obtained with the original clone, $3 \mathrm{CBo}$. For Northern hybridization, ${ }^{32} \mathrm{P}$-labeled antisense cRNA probes were generated using either T7 or T3 RNA polymerases. For in situ hybridization, sense and antisense ${ }^{35} \mathrm{~S}$-labeled cRNA probes were generated. A part of the $\mathrm{rpL7}$ cDNA (246 bp, nts 359-604; GenBank accession \# M29016) was subcloned into pCR-Script SK(+) vector and used as a template for synthesis of ${ }^{32} \mathrm{P}$-labeled antisense cRNA probe with T7 polymerase. The probes had specific activities of

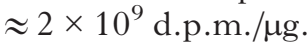

\section{In situ hybridization}

In situ hybridization was performed as previously described (Das et al. 1994, Lim et al. 1997). Frozen uterine sections $(10 \mu \mathrm{m})$ were mounted onto poly-L-lysine coated slides. When required, frozen sections were cut serially to detect the sites of blastocysts. Sections were fixed in $4 \%$ paraformalde- hyde in PBS for $15 \mathrm{~min}$ at $4{ }^{\circ} \mathrm{C}$. Following prehybridization, sections were hybridized to ${ }^{35} \mathrm{~S}$-labeled antisense cRNA probes for $4 \mathrm{~h}$ at $45^{\circ} \mathrm{C}$. As negative controls, uterine sections were hybridized with the ${ }^{35} \mathrm{~S}$-labeled sense probes. After hybridization and washing, the sections were incubated with RNase-A $(20 \mu \mathrm{g} / \mathrm{ml})$ at $37^{\circ} \mathrm{C}$ for $20 \mathrm{~min}$. RNase-A resistant hybrids were detected within 5-7 days of autoradiography using Kodak NTB-2 liquid emulsion. The slides were post-stained with hematoxylin and eosin.

\section{RESULTS}

\section{Detection of genes preferentially expressed in the mouse uterus at the time of attachment reaction by $\mathrm{mRNA}$ differential display}

To identify genes that are preferentially expressed in the uterus during initial embryo-uterine interactions, the mRNA differential display method was employed to compare mRNA species expressed in the uterus prior to the attachment reaction at $1800 \mathrm{~h}$ with those expressed at the time of attachment reaction $(2300 \mathrm{~h})$ on day 4 of pregnancy. Several mRNA species were obtained which exhibited upregulation in the uterus with the initiation of embryo implantation. One of the eight genes found to be upregulated in the implantation sites at $2300 \mathrm{~h}$ was designated $3 \mathrm{CBo}$ (Fig. 1a). The induction of this gene was also confirmed by Northern blot hybridization using the same RNA samples used for differential display (Fig. 1b). The sequence analysis of $3 \mathrm{CBo}$ identified the clone as cyclin D3. To further verify the identity of this clone, we obtained an additional cDNA clone $(\mathrm{Cd} 3)$ for mouse cyclin D3 by RT/PCR. Southern blot analysis of genomic tail DNA, using both clones (3CBo and $\mathrm{Cd} 3$ ) as probes showed the similar pattern of hybridization (Fig. 1c), providing evidence that both clones were of the same gene product. Subsequently, all Northern and in situ hybridization experiments were performed using the clone $3 \mathrm{CBo}$.

\section{Northern blot analysis of cyclin D3 mRNAs in the peri-implantation mouse uterus}

As shown in Fig. $2 a$, Northern blot hybridization detected a transcript of cyclin D 3 mRNA $(2.3 \mathrm{~kb})$ in the heart, kidney, lung, ovary, spleen, stomach, testis and uterus. During the peri-implantation period (days 1-8), the abundance of cyclin D3 mRNA was lower on days 1 and 2 , modest on days $3-5$, and highest on days $6-8$ (Fig. 2b). The levels of a house-keeping gene, rpL7, did not show much variation during this period. 


\section{Cell-specific expression of cyclin D3 mRNA in the peri-implantation mouse uterus and in artificially induced deciduoma}

If cyclin D3 is important for implantation/ decidualization, it should exhibit temporal and cell-specific expression in the peri-implantation uterus. Thus, the distribution of cyclin D3 mRNA in the peri-implantation uterus was examined by in situ hybridization (Fig. 3). On days 1 and 2 of pregnancy, low levels of autoradiographic signals of cyclin D3 mRNA were noted in the luminal and glandular epithelia (Fig. 3a), whereas on days 3 and 4 , low levels of signals were localized in both stromal and epithelial cells (Fig. 3b). On day 5, increased autoradiographic signals were noted primarily in the decidualizing stroma both at the mesometrial and the antimesometrial poles (Fig. 3c). The luminal and glandular epithelial cells also showed low levels of signals on this day. On days 6 and 7, strong positive signals were detected in the SDZ at both the mesometrial and the

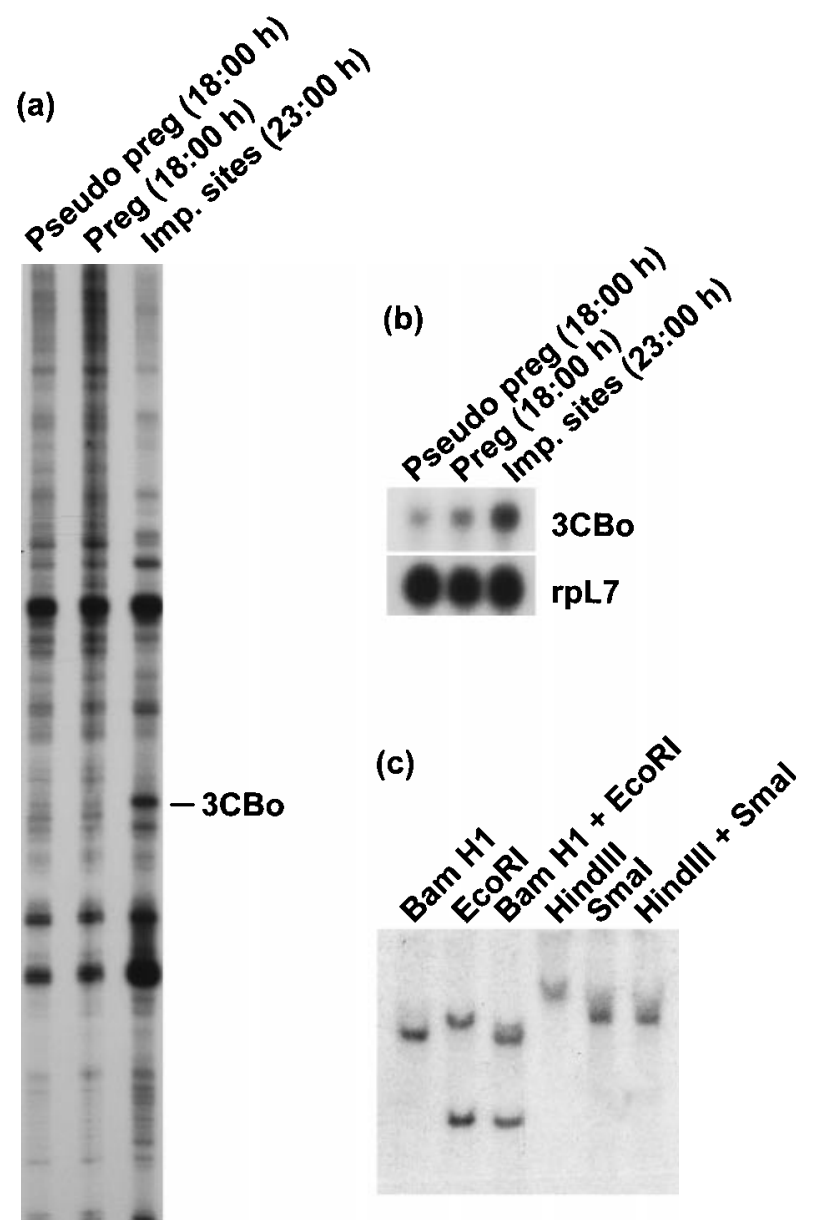

antimesometrial poles (Fig. 3d). Moreover, low levels of signals were detected in the circular muscle layer. In contrast, with the progression of decidualization on day 8 , signals in the SDZ at the antimesometrial pole decreased, but strong signals were retained in cells in the mesometrial decidual bed, including in a subpopulation of 'cords' of cells. These latter cells are perhaps the endothelial cells which participate in angiogenesis and placentation, since vascular endothelial growth factor receptors are also expressed in these cells (Chakraborty et al. 1995). The autoradiographic signals were also noted in the embryo (Fig. 3e).

In contrast to decidualization during normal pregnancy, the artificially induced deciduoma on day 6 of pseudopregnancy showed the accumulation of cyclin D3 mRNA in the decidual bed, primarily at the antimesometrial pole (Fig. 3f). The levels of accumulation were low compared with those in normal decidua (Fig. $3 f$ vs $3 \mathrm{~d}$ ). In the case of artificially induced deciduoma on day 8 , the accumulation of mRNA in decidual cells occurred in a similar fashion as that of normal pregnancy on day 8 , although in the latter case the expression was more intense in decidualized stroma at the presumptive site of placentation (Fig. $3 g$ ).

FIGURE 1. (a) Differential display of uterine mRNAs on day 4 of pregnancy and pseudopregnancy. Three different RNA samples from day 4 uterus during pseudopregnancy (Pseudo preg) or pregnancy (Preg) at $1800 \mathrm{~h}$, and the implantation sites (Imp. sites) at $2300 \mathrm{~h}$ on day 4 of pregnancy were compared by differential display using one base anchored modified primer, LHT11C (Liang et al. 1994), with the arbitrary primer, LHAP3 (Liang et al. 1994). The PCR amplified cDNA fragment $(3 \mathrm{CBo})$ was subsequently cloned for cyclin D3. (b) Northern blot hybridization of the uterine RNA samples used for differential display with a cRNA probe obtained from the $3 \mathrm{CB}$ o clone. Three different total RNA samples $(6 \cdot 0 \mu \mathrm{g})$ from day 4 uterus during pseudopregnancy or pregnancy as described above for differential display, were separated by agaroseformaldehyde gel electrophoresis, transferred, UV cross-linked to nylon membrane and hybridized sequentially to ${ }^{32} \mathrm{P}$-labeled $3 \mathrm{CBo}$ and rpL7 antisense cRNA probes. (c) Southern blot hybridization of the $3 \mathrm{CBo}$ clone using the genomic tail DNA following digestion with different restriction enzymes. Genomic tail DNA $(5 \cdot 0 \mu \mathrm{g})$ was digested with BamHI, EcoRI, BamHI+EcoRI, HindIII, SmaI and HindIII+SmaI overnight at $37^{\circ} \mathrm{C}$, Southern blotted and hybridized to the $3 \mathrm{CBo}$ cRNA probe. The autoradiographic signals for the Southern hybridization were detected after 3 days of exposure. 


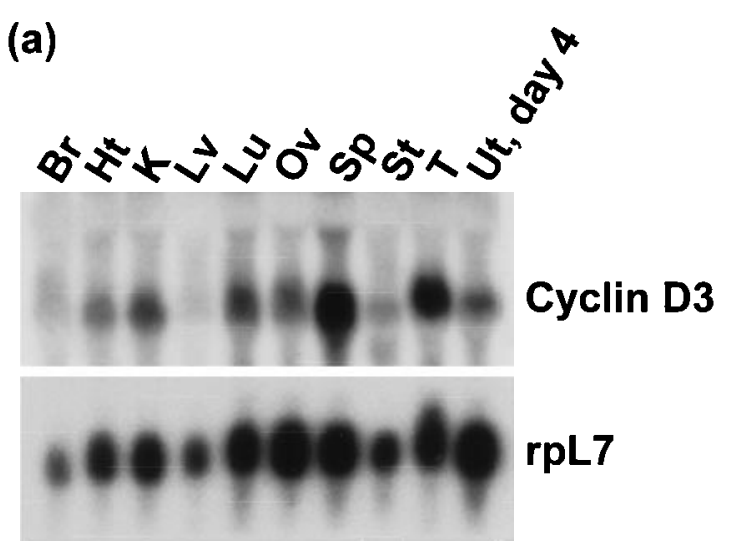

(b)

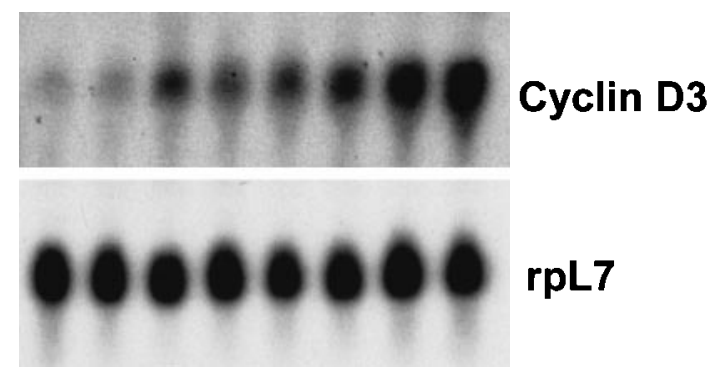

\section{$\begin{array}{llllllll}1 & 2 & 3 & 4 & 5 & 6 & 7 & 8\end{array}$ Day of Pregnancy}

FIGURE 2. (a) Northern hybridization of cyclin D3 mRNA in adult mouse tissues. Br, brain; Ht, heart; K, kidney; Lv, liver; Lu, lung; Ov, ovary; Sp, spleen; St, stomach; T, testis; and Ut, day 4 , uterus on day 4 of pregnancy. (b) Northern blot hybridization of cyclin D3 mRNA in the peri-implantation mouse uterus. Total RNA $(6 \mu \mathrm{g})$ was separated by agarose-formaldehyde gel electrophoresis, transferred, UV cross-linked to nylon membrane and hybridized sequentially to ${ }^{32} \mathrm{P}$-labeled $3 \mathrm{CBo}$ and rpL7 antisense cRNA probes. Days of pregnancy (days 1-8) are indicated. Autoradiographic exposures were $6 \mathrm{~h}$ for cyclin D3 and $2 \mathrm{~h}$ for rpL7.

\section{In situ hybridization of cyclin D3 mRNAs in the delayed implanting mouse uterus}

To examine whether the expression of cyclin D3 gene in the uterus requires the presence of an active blastocyst, in situ hybridization was carried out on uterine sections obtained from $\mathrm{P}_{4}$-treated delayed implanting mice or after the initiation of blastocyst activation for implantation by an $\mathrm{E}_{2}$ injection. Low levels of hybridization signals for cyclin D3 were detected in the epithelial and stromal cells surrounding dormant blastocysts during $\mathrm{P}_{4}$ treatment (Fig. $4 a$,b). In contrast, following the termination of delayed implantation by an $\mathrm{E}_{2}$ injection, the accumulation of cyclin D3 mRNA became distinctly evident in the decidualizing stromal cells surrounding the implanting blastocysts (Fig. $4 c$,d). It should be recalled that the attachment reaction (blue reaction) occurs at $18-24 \mathrm{~h}$ after $\mathrm{E}_{2}$ injection in $\mathrm{P}_{4}$-treated delayed implanting mice. Thus, the cyclin D3 gene expression at $24 \mathrm{~h}$ following termination of delayed implantation was similar to that detected in normal pregnancy on the morning of day 5 (Fig. $4 c$,d vs $3 \mathrm{c}$ ).

\section{Cyclin D3 expression in Hoxa-10 $(-/-)$ uteri}

Although the results obtained thus far suggested that the expression of cyclin D3 is induced in parallel with the onset of the decidualization during normal pregnancy or pseudopregnancy, whether this expression is essential for decidualization is not known. In furthering this question, we examined the expression of cyclin D3 in Hoxa-10(-/-) mice, which exhibited defective implantation and decidualization (Benson et al. 1996). Intraluminal oil infusions were performed in both horns on day 4 of pseudopregnancy in both the wild-type and Hoxa-10( $-/-)$ mice. The expression of cyclin D3 mRNA was examined in one horn on day 5 , and the extent of decidualization of the remaining contralateral horn was examined on day 8. As shown in Fig. 5, the expression of cyclin D3 mRNA was severely affected in Hoxa-10 $(-/-)$ uteri (Fig. 5a) as compared with that in wild-type $(+/+)$ uteri (Fig. $5 b$ ). This reduced expression of cyclin D3 in the Hoxa-10 $(-/-)$ uteri was correlated with reduced decidualization of the remaining horn on day 8 (30\% of wild-type) (data not shown). The results suggest that the decreased expression of cyclin D3 could be a cause for the failure of decidualization.

\section{DISCUSSION}

The technique of differential display of mRNA is being extensively used to identify differential expression of genes under specific experimental or physiological conditions (Liang \& Pardee 1992). Applying this technique, we searched for genes which could be involved in implantation and decidualization processes. Cyclin D3, one of the eight genes showing upregulation in the uterus at the sites of implantation, was primarily expressed in the decidualizing stromal cells during implantation. 

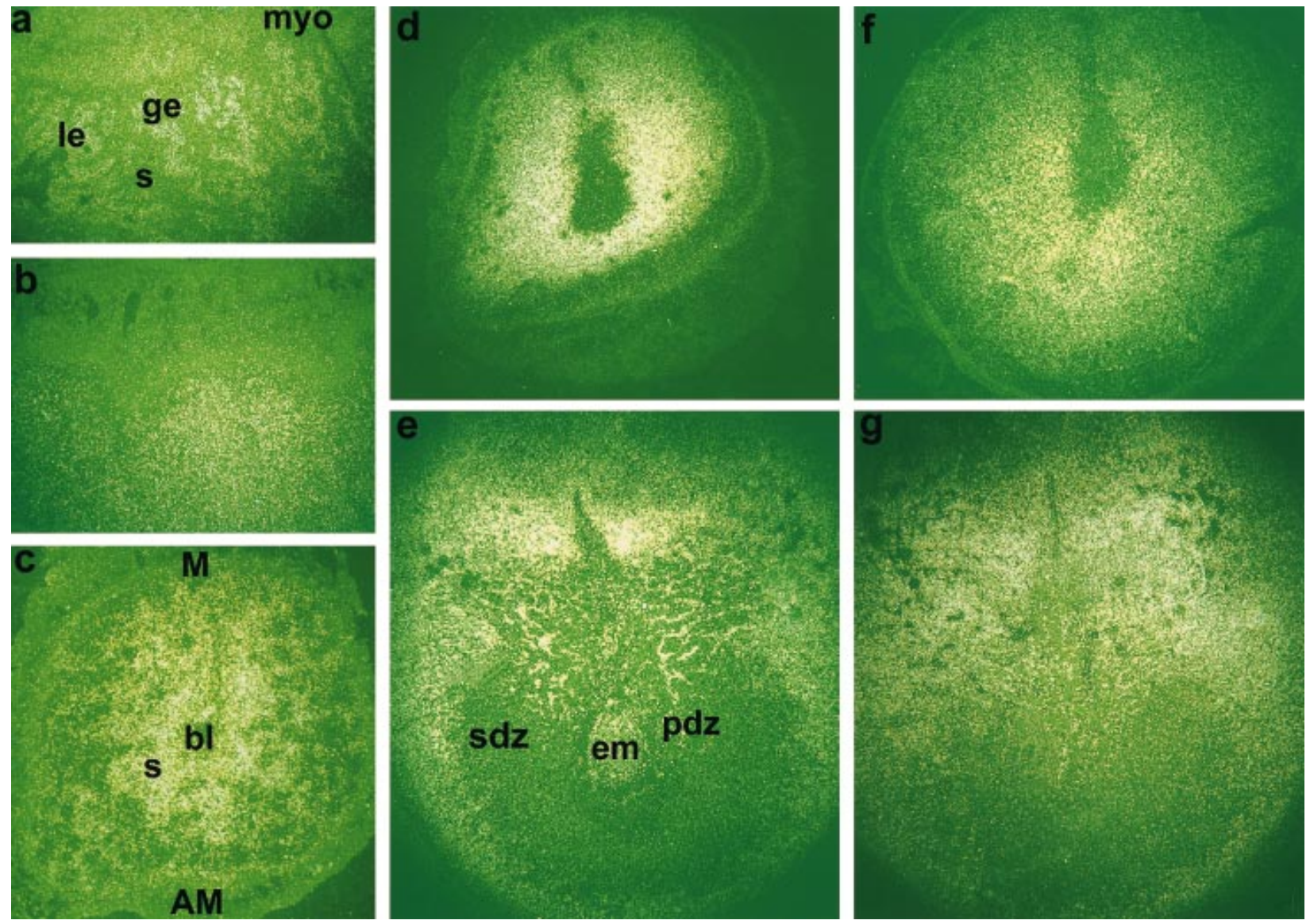

FIGURE 3. In situ hybridization of cyclin D3 mRNA in the peri-implantation mouse uterus and in the experimentally induced deciduoma on days 6 and 8. Darkfield photomicrographs of representative longitudinal sections of uteri at $0900 \mathrm{~h}$ on days 1 (a) and 4 (b) are shown at $\times 100$. Darkfield photomicrographs of cross-sections of uteri on days 5 (c), 6 (d) and 8 (e) of pregnancy and of deciduoma on days 6 (f) and 8 (g) of pseudopregnancy are shown. Pictures are shown at $\times 40$ for days 5 and 6 , and at $\times 20$ for day 8 . bl, blastocyst; le, luminal epithelium; ge, glandular epithelium; s, stroma; myo, myometrium; pdz, primary decidual zone; sdz, secondary decidual zone; M, mesometrial pole; AM, antimesometrial pole; em, embryo.

This is the first report demonstrating cell-specific expression of cyclin D3 mRNA in the uterus during early pregnancy in the rodent and provides evidence that uterine cyclin D3 could be important for implantation/decidualization. The expression of this gene in decidualizing stromal cells is not dependent upon the presence of blastocysts, because the induction also occurs in experimentally induced deciduoma.

The uterus is the major target for estrogen and $\mathrm{P}_{4}$ actions. Although these steroids primarily direct uterine cell proliferation and differentiation during the peri-implantation period in a spatiotemporal manner, the molecular and cellular mechanisms involved in these processes are poorly understood. In the mouse, an extremely low level of estrogen is required to elicit implantation/decidualization in a
$\mathrm{P}_{4}$-primed uterus, suggesting that estrogen effects in the uterus are amplified by other local mediators. This speculation is consistent with recent observations of uterine cell-specific expression of several growth factors and their receptors during implantation (reviewed in Das et al. 1995). The expression of cyclin D3 mRNA in the uterine epithelium on day 1 of pregnancy under the influence of preovulatory estrogen is correlated with epithelial cell proliferation, while stromal cell proliferation under the influence of rising $\mathrm{P}_{4}$ and preimplantation ovarian estrogen secretion on day 4 could be associated with stromal cell proliferation. The expression of cyclin D3 mRNA in the decidualizing stromal cells suggests that this gene product is another factor involved in potentiating estrogen effects in the uterus during implantation/ 

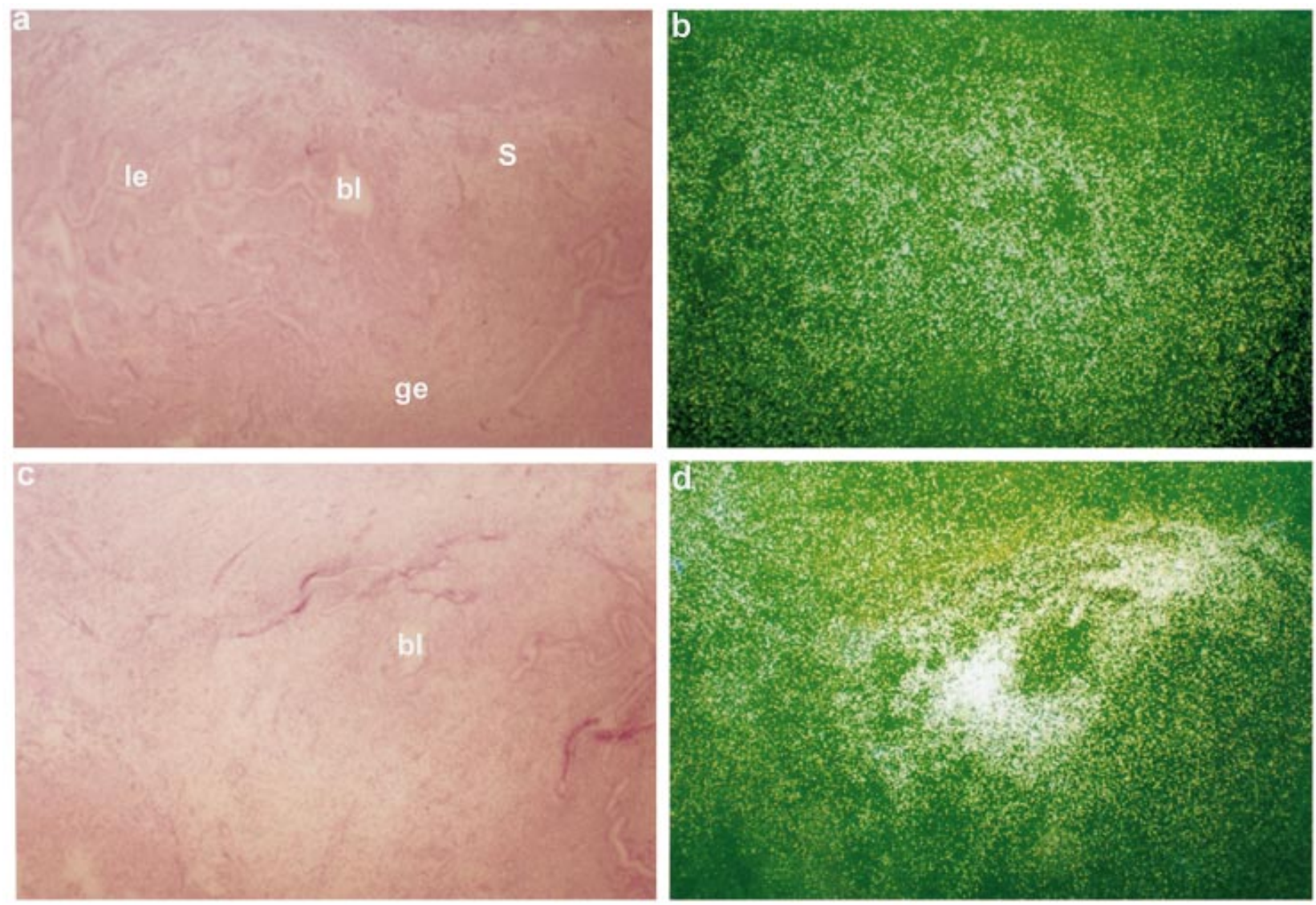

FIGURE 4. In situ hybridization of cyclin D3 mRNAs in uteri from $\mathrm{P}_{4}$-treated delayed implanting mice before and after an $\mathrm{E}_{2}$ injection. Bright- and dark-field photomicrographs of longitudinal uterine sections are shown at $\times 100$. (a and b) Representative sections from $\mathrm{P}_{4}$-treated delayed implanting mice hybridized with cyclin D3 cRNA probes. (c and d) Representative sections from $\mathrm{P}_{4}$-treated delayed implanting mice after an $\mathrm{E}_{2}$ injection showing signals for cyclin D3 mRNA at the implantation sites. bl, blastocyst; le, luminal epithelium; ge, glandular epithelium; s, stroma.

decidualization. Indeed, there is evidence that the expression of D-type cyclins and the cyclindependent kinases are regulated by estrogen in the rodent uterus (Altucci et al. 1997, Geum et al. 1997, Prall et al. 1997). The heightened expression of cyclin D3 mRNA in decidualizing stroma could be due to combined effects of estrogen and $\mathrm{P}_{4}$ in the presence of a deciduogenic stimulus. This finding suggests that the regulation of this gene in the uterus could be modulated by estrogen and/or $\mathrm{P}_{4}$ in a cell-specific manner. This is consistent with cell-specific expression of cyclin D3 mRNA in the ovariectomized uterus after estrogen and/or $\mathrm{P}_{4}$ treatments (data not shown).

Normally, estrogen induces progesterone receptors (PR) in the uterus. However, the nature of the interactions between these two steroids which trigger the implantation and decidualization processes remain undefined. The dramatic downregu- lation of the nuclear estrogen receptor- $\alpha$ (ER- $\alpha$ ) (Das et al. 1996) and very low levels of ER- $\beta$ (our unpublished observation) in the deciduum suggest that the participation of nuclear ERs in the process of decidualization is limited (Das et al. 1996). This is consistent with the observation that $\mathrm{P}_{4}$, not estrogen, is an absolute requirement for sustained decidualization in the rodent. However, it is to be noted that estrogen is essential for the initiation of the implantation in the $\mathrm{P}_{4}$-primed uterus (reviewed in Dey 1996).

The expression of cyclin D3 mRNA in the rapidly proliferating stromal cells (decidual cell reaction) surrounding the blastocyst on day 5 and in the SDZ, but not in the PDZ, on days 6 and 7 suggest that this gene is involved in extensive cell proliferation during decidual cell reaction. In contrast, low levels of cyclin D3 mRNA in the SDZ at the antimesometrial pole on day 8 are associated 

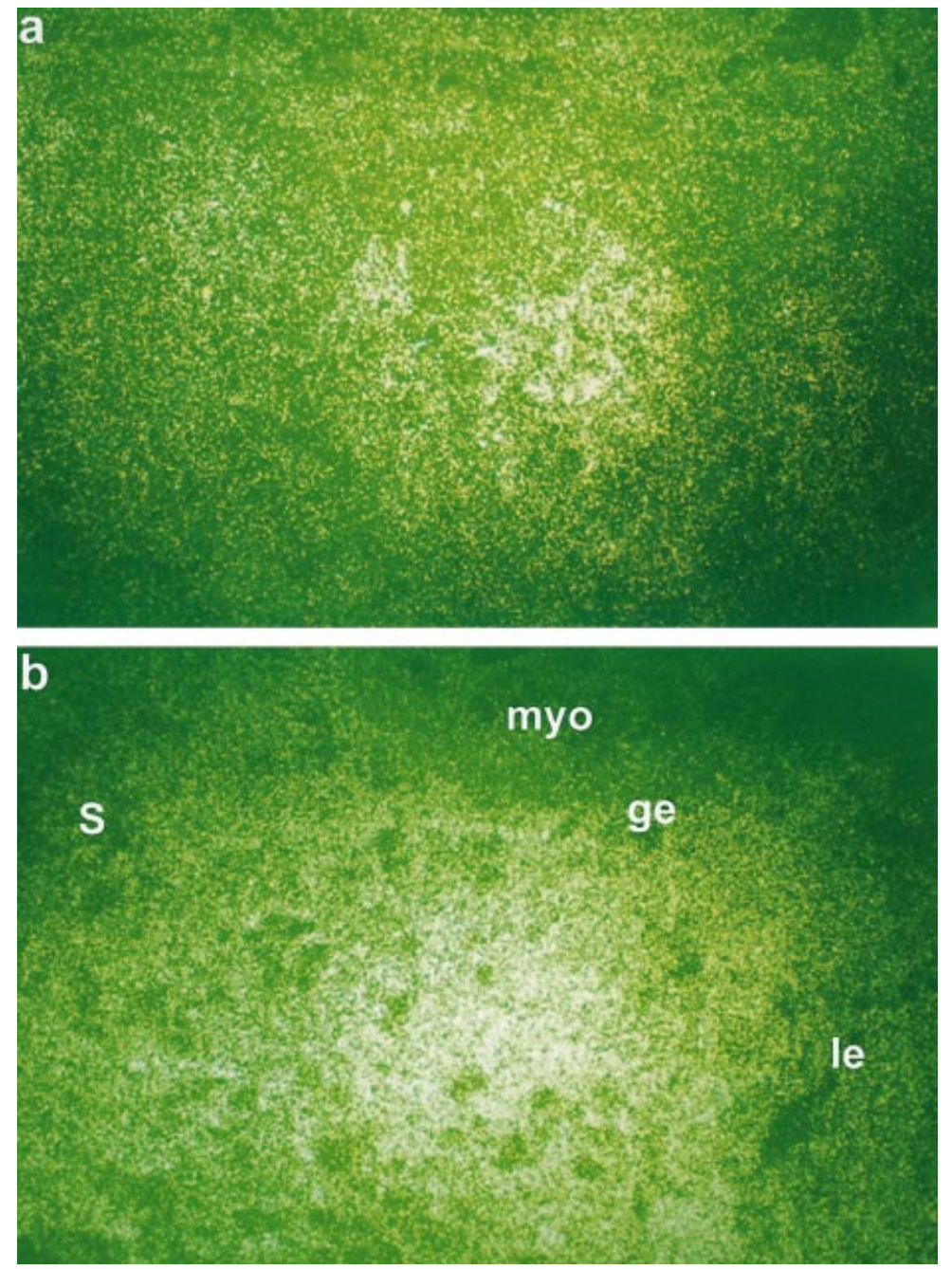

FIGURE 5. In situ hybridization of cyclin D3 mRNA in Hoxa-10 $(-/-)$ and in wild-type mouse uteri. Hoxa-10(+/+) or Hoxa-10 $(-/-)$ mice received intraluminal oil infusion in both horns on day 4 of pseudopregnancy. On day 5, one horn was removed and in situ hybridization was performed for cyclin D3, the remaining horn was left untouched for recording decidualization. Darkfield photomicrographs of representative longitudinal sections of uteri from Hoxa-10 $(-/-)$ (a) or Hoxa-10(+/+) (b) are shown at $\times 40$. le, luminal epithelium; ge, glandular epithelium; s, stroma; myo, myometrium.

with diminishing cell proliferation. This suggestion is supported by our observation in Hoxa-10( $-/-)$ mice. Hoxa-10 is expressed in the stroma on day 4 and in decidualizing stroma on day 5 of pregnancy, suggesting that this homeobox gene is important for stromal cell proliferation and subsequent decidualization. Indeed, the null mutation of this gene causes decidualization failure in the mouse (Benson et al. 1996, Ma et al. 1998). Reduced levels of cyclin D3 mRNA in Hoxa-10 $(-/-)$ uteri after appli- cation of a deciduogenic stimulus suggests that the expression of this D-type cyclin could be associated with Hoxa-10 effects during decidualization. Alternatively, reduced uterine expression of cyclin D3 in these mice could be secondary to decidualization failure.

The expression of cyclin D3 mRNA at the mesometrial pole on day 8 suggests that this protein could be involved in angiogenesis and placentation. D-type cyclins are involved in cell growth and are 
known to possess distinct signaling pathways (Mann et al. 1997, Sun et al. 1996). A recent report indicates that the expression of cyclin D2 is critical for the hormone-induced proliferation and differentiation of granulosa cells (Robker \& Richards 1998). A distinct switch in the expression of cyclin D3 to D1 during trophoblast giant cell differentiation in the rodent has also been reported (MacAuley et al. 1998). Although D-type cyclins are expressed in an overlapping and apparently redundant fashion in the proliferating tissues (Peters 1994, Sherr 1994), spatiotemporal expression of cyclin D1 and cyclin $\mathrm{D} 2$ in the peri-implantation uterus has not yet been examined.

\section{ACKNOWLEDGEMENTS}

We thank Lisa Schlehuber, Jue Wang and Xuemei Zhao for their technical assistance during this investigation. This research was supported in part by grants from NIEHS, Research Triangle Park, NC, USA (ES 07814) to S K Das, NICHD, Bethesda, MD, USA (HD-12304 and HD-29968) to S K Dey, and core support from NICHD center grants (HD-02528 and HD-33994).

\section{REFERENCES}

Altucci L, Addeo R, Cicatiello L, Germano D, Pacilio C, Battista T, Cancemi M, Petrizzi VB, Bresciani F \& Weisz A 1997 Estrogen induces early and timed activation of cyclindependent kinases 4, 5, and 6 and increases cyclin messenger ribonucleic acid expression in rat uterus. Endocrinology 138 978-984.

Benson GV, Lim H, Paria BC, Satokata I, Dey SK \& Maas RL 1996 Mechanism of reduced fertility in Hoxa-10 mutant mice: uterine homeosis and loss of maternal Hoxa-10 expression. Development 122 2687-2696.

Chakraborty I, Das SK \& Dey SK 1995 Differential expression of vascular endothelial growth factor and its receptor mRNAs in the mouse uterus around the time of implantation. Fournal of Endocrinology 147 339-352.

Das SK, Wang X-N, Paria BC, Damm D, Abraham JA, Klagsbrun M, Andrews GK \& Dey SK 1994 Heparinbinding EGF-like growth factor gene is induced in the mouse uterus temporally by the blastocyst solely at the site of its apposition: a possible ligand for interaction with blastocyst EGF-receptor in implantation. Development $\mathbf{1 2 0}$ 1071-1083.

Das SK, Chakraborty I, Paria BC, Wang X-N, Plowman GD \& Dey SK 1995 Amphiregulin is an implantation-specific and progesterone-regulated gene in the mouse uterus. Molecular Endocrinology 9 691-705.

Das N, Wang J \& Dey SK 1996 Uterine preparation for implantation in the mouse is associated with coordinate expression of estrogen-responsive finger protein and estrogen receptor. Molecular Reproduction and Development $\mathbf{4 6}$ 499-506.

Dey SK 1996 Implantation. In Reproductive Endocrinology, Surgery, and Technology, pp 421-434. Eds EY Adashi, JA Rock \& Z Rosenwaks. New York: Lippincott-Raven Publishers.
Enders AC 1976 Anatomical aspects of implantation. Fournal of Reproduction and Fertility 2 1-15.

Enders AC \& Schlafke S 1967 A morphological analysis of the early implantation stages in the rat. American fournal of Anatomy 120 185-226.

Geum D, Sun W, Paik SK, Lee CC \& Kim K 1997 Estrogeninduced cyclin D1 and D3 gene expressions during mouse uterine cell proliferation in vivo: differential induction mechanism of cyclin D1 and D3. Molecular Reproduction and Development 46 450-458.

Grana X \& Reddy EP 1995 Cell cycle control in mammalian cells: role of cyclins, cyclin-dependent kinases, growth suppressor genes and cyclin-dependent kinase inhibitors. Oncogene 11 211-219.

Han JH, Stratowa C \& Rutter WJ 1987 Isolation of full-length putative rat lysophospholipase cDNA using improved methods for mRNA isolation and cDNA cloning. Biochemistry 26 1617-1625.

Herzinger T \& Reed SI 1998 Cyclin D3 is rate-limiting for the $\mathrm{G}_{1} / \mathrm{S}$ phase transition in fibroblasts. Fournal of Biological Chemistry 273 14958-14961.

Huet-Hudson YM, Andrews GK \& Dey SK 1989 Cell typespecific localization of c-myc protein in the mouse uterus: modulation by steroid hormones and analysis of the periimplantation period. Endocrinology 125 1683-1690.

Hunter T \& Pines J 1994 Cyclins and cancer II: cyclin D and CDK inhibitors come of age. Cell 79 551-555.

Liang P \& Pardee AB 1992 Differential display of eukaryotic messenger RNA by means of the polymerase chain reaction. Science 257 967-971.

Liang P, Averboukh L \& Pardee AB 1993 Distribution and cloning of eukaryotic mRNAs by means of differential display: refinements and optimization. Nucleic Acids Research 21 3269-3275.

Liang $\mathrm{P}$, Zhu W, Zhang X, Guo Z, O'Connell RP, Averboukh L, Wang F \& Pardee AB 1994 Differential display using one-base anchored oligo-dT primers. Nucleic Acids Research 22 5763-5764.

Lim H, Paria BC, Das SK, Dinchuk JE, Langenbach R, Trzaskos JM \& Dey SK 1997 Multiple female reproductive failures in cyclooxygenase 2-deficient mice. Cell 91 197-208.

Ma L, Benson GV, Lim H, Dey SK \& Maas RL 1998 Abdominal B (AbdB) Hoxa genes: regulation in adult uterus by estrogen and progesterone and repression in Mullerian duct by the synthetic estrogen diethylstilbestrol (DES). Developmental Biology 197 141-154.

MacAuley A, Cross JC \& Werb Z 1998 Reprogramming the cell cycle for endoreduplication in rodent trophoblast cells. Molecular Biology of Cell 9 795-807.

Mann DJ, Higgins T, Jones NC \& Rozengurt E 1997 Differential control of cyclins D1 and D3 and the cdk inhibitor $\mathrm{p} 27^{\mathrm{kip} 1}$ by diverse signalling pathways in Swiss $3 \mathrm{~T} 3$ cells. Oncogene 14 1759-1766.

Nilsson O 1974 The morphology of blastocyst implantation. Fournal of Reproduction and Fertility 39 187-194.

Paria BC, Huet-Hudson YM \& Dey SK $1993 a$ Blastocyst's state of activity determines the 'window' of implantation in the mouse receptive uterus. Proceedings of the National Academy of Sciences of the USA 90 10159-10162.

Paria BC, Das SK, Andrews GK \& Dey SK $1993 b$ Expression of the epidermal growth factor receptor gene is regulated in mouse blastocysts during delayed implantation. Proceedings of the National Academy of Sciences of the USA $9055-59$.

Peters G 1994 The D-type cyclins and their role in tumorigenesis. Fournal of Cell Science (Suppl) 18 89-96.

Pines J 1995 Cyclins and cyclin-dependent kinases: a biochemical view. Biochemical Fournal 308 697-711. 
Prall OWJ, Sarcevic B, Musgrove EA, Watts CKW \& Sutherland RL 1997 Estrogen-induced activation of cdk4 and cdk2 during G1-S phase progression is accompanied by increased cyclin D1 expression and decreased cyclindependent kinase inhibitor association with cyclin E-cdk2. Fournal of Biological Chemistry 272 10882-10894.

Psychoyos A 1973 Endocrine control of egg implantation. In Handbook of Physiology, pp 187-215. Eds RO Greep, EG Astwood \& SR Geiger. Washington, DC: American Physiological Society.

Robker RL \& Richards JS 1998 Hormone-induced proliferation and differentiation of granulosa cells: a coordinated balance of the cell cycle regulators cyclin D2 and p2 $7^{\text {kip1 }}$. Molecular Endocrinology 12 924-940.
Sherr CJ $1994 \mathrm{G}_{1}$ phase progression: cyclin on cue. Cell 79 551-555.

Sun W, Lee DK, Lee CC \& Kim K 1996 Differential expression of D-type G1 cyclins during mouse development and liver regeneration in vivo. Molecular Reproduction and Development 43 414-420.

Weinberg RA 1995 The retinoblastoma protein and cell cycle control. Cell 81 323-330.

Yoshinaga K \& Adams CE 1966 Delayed implantation in the spayed, progesterone-treated adult mouse. Fournal of Reproduction and Fertility 12 593-595.

RECEIVED 16 July 1998 